Louisiana State University

LSU Digital Commons

Faculty Publications

Department of Biological Sciences

$1-1-2005$

\title{
Norleucine, a natural occurrence in a novel ergot alkaloid $\mathbf{y}$ - ergokryptinine
}

L. Cvak

Teva Pharmaceutical Industries Ltd.

A. Jegorov

Teva Pharmaceutical Industries Ltd.

P. Sedmera

Institute of Microbiology of the Academy of Sciences of the Czech Republic

I. Císařová

Charles University

J. Čejka

University of Chemistry and Technology, Prague

See next page for additional authors

Follow this and additional works at: https://digitalcommons.Isu.edu/biosci_pubs

\section{Recommended Citation}

Cvak, L., Jegorov, A., Sedmera, P., Císařová, I., Čejka, J., Kratochvíl, B., \& Pakhomova, S. (2005). Norleucine, a natural occurrence in a novel ergot alkaloid y-ergokryptinine. Amino Acids, 29 (2), 145-150.

https://doi.org/10.1007/s00726-005-0180-2

This Article is brought to you for free and open access by the Department of Biological Sciences at LSU Digital Commons. It has been accepted for inclusion in Faculty Publications by an authorized administrator of LSU Digital Commons. For more information, please contact ir@lsu.edu. 


\section{Authors}

L. Cvak, A. Jegorov, P. Sedmera, I. Císařová, J. Čejka, B. Kratochvíl, and S. Pakhomova 


\title{
Norleucine, a natural occurrence in a novel ergot alkaloid $\gamma$-ergokryptinine
}

\author{
L. Cvak ${ }^{1}$, A. Jegorov ${ }^{2}$, P. Sedmera ${ }^{3}$, I. Císařová ${ }^{4}$, J. Čejka ${ }^{5}$, B. Kratochvíl ${ }^{5}$, and S. Pakhomova ${ }^{6}$ \\ ${ }^{1}$ IVAX Pharmaceuticals, R\&D, Opava-Komárov, Czech Republic \\ ${ }^{2}$ IVAX Pharmaceuticals, R\&D, České Budějovice, Czech Republic \\ ${ }^{3}$ Institute of Microbiology, Academy of Sciences of the Czech Republic, Prague, Czech Republic \\ ${ }^{4}$ Department of Inorganic Chemistry, Charles University, Prague, Czech Republic \\ ${ }^{5}$ Department of Solid State Chemistry, Institute of Chemical Technology, Prague, Czech Republic \\ ${ }^{6}$ Department of Biological Sciences, Louisiana State University, Life Sciences Bldg, Baton Rouge, Louisiana, U.S.A.
}

Received September 29, 2004

Accepted November 11, 2004

Published online February 23, 2005; (C) Springer-Verlag 2005

Summary. A novel natural peptide ergot alkaloid $\gamma$-ergokryptinine containing norleucine has been isolated from ergot sclerotia of the fieldgrowing parasitic fungus Claviceps purpurea CCM 8059. Its structure was deduced from the NMR and mass spectral data. The final structural proof was provided by the crystal structure determination, which is the first X-ray structure of a natural Nle-containing secondary metabolite. The conformations of three ergopeptinines: $\gamma$-ergokryptinine, ergoladinine, and $\alpha$-ergokryptinine were compared.

Keywords: Norleucine - Ergot alkaloids $-\gamma$-Ergokryptinine - Crystal structure determination

\section{Introduction}

It seemed until recently that the number of ergot alkaloids of peptidic type is limited to 12 by a combination of 3 amino acids (Ala, $\alpha$-Abu, and Val) at the first and 4 amino acids (Val, Phe, Leu, Ile) at the second position of the tripeptide moiety of ergopeptines (Stadler, 1982; Buchta and Cvak, 1999). From the historical point of view, the forgotten ergoheptine, which was described based on the paper chromatography only (Abe et al., 1970; Pöhm, 1954), was probably the later identified $\beta$-ergokryptine (Schlientz et al., 1967). During the last two decades of $20^{\text {th }}$ century several new alkaloids have been prepared by directed biosynthesis (Beacco et al., 1978; Baumert, 1982; Flieger et al., 1984; Crespi-Perellino et al., 1992), but only a few of new ergopeptines were found in nature with the genus Claviceps (Bianchi et al., 1982; Crespi-Perellino et al., 1993; Powell et al., 1990; Cvak et al., 1994; Szántay et al., 1994; Cvak et al., 1996; Halada et al., 1998), other fungal genera, e.g., Acremonium (Yates et al., 1985), Sphacelia (Atwell and Mantle, 1981), Dicyma (Vázquez et al., 2003), and in higher plants (Jenett-Siems et al., 1994). Analyses of amino acids in hydrolysates of sclerotia of the parasitic fungus Claviceps purpurea and of crude alkaloid mixtures have revealed the presence of some additional aliphatic amino acids and led to the prediction of the existence of yet unknown natural ergot alkaloids (Jegorov et al., 1997). Here we report the identification and crystal structure determination of a novel alkaloid named $\gamma$-ergokryptinine (Fig. 1).

\section{Material and methods}

\subsection{Instruments and methods}

NMR spectra were measured on a Varian Inova-400 $\left(399.88 \mathrm{MHz}\right.$ for ${ }^{1} \mathrm{H}$, $100.55 \mathrm{MHz}$ for ${ }^{13} \mathrm{C}, \mathrm{CDCl}_{3}, 30^{\circ} \mathrm{C}$ ). Following experiments have been performed: H, C, HOM2DJ, gCOSY, TOCSY, HMQC, gHMQC, 1DTOCSY. Chemical shifts are reported in $\delta$-scale. Positive-ion ESI spectra were recorded on a Finnigan LCQ ion trap instrument (Finnigan MAT, Bremen, Germany). IR spectrum was measured on Nicolet Nexus in $\mathrm{KBr}$ pellet and UV spectrum was recorded on Varian DMS 300 in acetonitrile.

\subsection{Isolation of $\gamma$-ergokryptinine}

Crude $\alpha$-ergokryptine $(70.0 \mathrm{~kg}$ ) was dissolved in the mixture of toluene (2701) and of methanol (701) and the solution was concentrated to the volume of about 1501 in vacuum and diluted by toluene (1501). The crystalline $\alpha$-ergokryptine was filtered off and washed by toluene. The mother liquors were concentrated to dryness and the residue was dissolved in methanol (81) and the solution was refluxed for 4 hours. The obtained crystalline product was filtered off and washed with methanol, giving a 


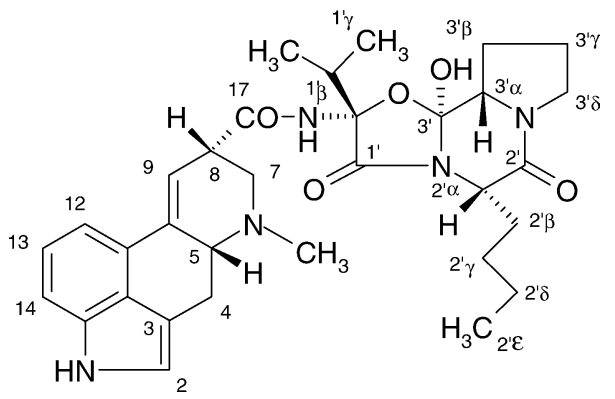

Fig. 1. Numbering scheme for NMR spectrum of $\gamma$-ergokryptinine mixture of ergopeptinines $(1620 \mathrm{~g})$. According to the HPLC analysis, the mixture consisted of $\alpha$-ergokryptinine (85.4\%), ergogalinine (3.7\%), ergocristinine (2.1\%), ergocorninine (2.4\%), ergoladinine (1.3\%), an unknown alkaloid (1.5\%), identified later as $\gamma$-ergokryptinine, and some other unknown alkaloids. The mixture of ergopeptinines $(500 \mathrm{~g})$ was chromatographed on 10 weight parts of silica gel (Merck, 60 A, 63-200 $\mu \mathrm{m}$ ) using dichloromethane with $0.5 \%$ methanol as eluent. The fraction containing the unknown alkaloid was chromatographed twice more using the same chromatographic system, giving a concentrate $(0.80 \mathrm{~g})$ which was crystallised from methanol, affording the mixture $(0.55 \mathrm{~g})$ of $\gamma$-ergokryptinine (59.4\%) and $\alpha$-ergokryptinine (35.0\%).

The $\gamma$-ergokryptinine concentrate $(0.50 \mathrm{~g})$ was purified by preparative HPLC on modified silica containing bonded aminopropyl groups (Column Separon SGX NH2, $250 \times 25 \mathrm{~mm}$, I.D., $5 \mu \mathrm{m}$, from Watrex,

Table 1. ${ }^{1} \mathrm{H}$ and ${ }^{13} \mathrm{C}$ NMR data of $\gamma$-ergokryptinine $\left(399.88\right.$ and $100.55 \mathrm{MHz}, \mathrm{CDCl}_{3}, 30^{\circ} \mathrm{C}$ )

\begin{tabular}{|c|c|c|c|c|c|c|c|}
\hline Atom & $\delta_{\mathrm{C}}$ & $\mathrm{m}$. & $\delta_{\mathrm{H}}$ & $\mathrm{n}_{\mathrm{H}}$ & $\mathrm{m}$. & $\mathrm{J}[\mathrm{Hz}]$ & $\mathrm{HMBC}(\mathrm{C}$ to $\mathrm{H})$ \\
\hline 2 & 118.37 & $\mathrm{D}$ & 6.908 & 1 & $\mathrm{dd}$ & $1.9,1.8$ & $\mathrm{NH}, 4 \mathrm{e}, 4 \mathrm{a}$ \\
\hline 3 & 110.02 & $\mathrm{~S}$ & - & 0 & & & $\mathrm{NH}, 2,4 \mathrm{e}, 4 \mathrm{a}$ \\
\hline \multirow[t]{2}{*}{4} & 27.56 & $\mathrm{~T}$ & 3.598 & 1 & $\mathrm{dd}$ & $14.3,5.4$ & 5 \\
\hline & & & 2.676 & 1 & ddd & $14.3,11.5,1.8$ & \\
\hline 5 & 62.84 & $\mathrm{D}$ & 3.239 & 1 & dddd & $11.5,5.4,2.2,2.1$ & $4 \mathrm{e}, 4 \mathrm{a}, 7 \mathrm{e}, 7 \mathrm{a}, 9, \mathrm{NMe}$ \\
\hline \multirow[t]{2}{*}{7} & 54.73 & $\mathrm{~T}$ & 3.161 & 1 & ddd & $11.9,1.3,1.2$ & $9, \mathrm{NMe}$ \\
\hline & & & 2.764 & 1 & $\mathrm{dd}$ & $11.9,3.7$ & \\
\hline 8 & 44.01 & $\mathrm{D}$ & 3.087 & 1 & $\mathrm{~m}$ & & $7 \mathrm{e}, 9$ \\
\hline 9 & 117.61 & $\mathrm{D}$ & 6.521 & 1 & ddd & $6.4,2.1,1.2$ & $5,7 \mathrm{e}, 8$ \\
\hline 10 & 137.29 & $\mathrm{~S}$ & - & 0 & & & $4 \mathrm{e}, 4 \mathrm{a}, 5,8,12$ \\
\hline 11 & 127.41 & $\mathrm{~S}$ & - & 0 & & & $9 a, 13$ \\
\hline 12 & 112.84 & $\mathrm{D}$ & 7.114 & 1 & dd & $7.2,1.1$ & 14 \\
\hline 13 & 123.40 & $\mathrm{D}$ & 7.155 & 1 & $\mathrm{dd}$ & $7.7,7.1$ & \\
\hline 14 & 110.16 & $\mathrm{D}$ & 7.220 & 1 & $\mathrm{dd}$ & $7.7,1.1$ & 12 \\
\hline 15 & 133.95 & $\mathrm{~S}$ & - & 0 & & & $\mathrm{NH}, 2,13$ \\
\hline 16 & 126.25 & $S$ & - & 0 & & & $\mathrm{NH}, 2,4 \mathrm{e}, 4 \mathrm{a}, 12,14$ \\
\hline 17 & 176.26 & S & - & 0 & & & $7 \mathrm{a}, 7 \mathrm{e}, 8,9, \mathrm{CONH}$ \\
\hline $\mathrm{NH}$ & - & - & 8.149 & 1 & d & 1.9 & \\
\hline $\mathrm{NMe}$ & 43.36 & Q & 2.629 & 3 & s & & $5,7 \mathrm{e}$ \\
\hline $\mathrm{CONH}$ & - & - & 9.949 & 1 & s & & \\
\hline $1^{\prime}$ & 165.37 & S & - & 0 & & & $\mathrm{CONH}$ \\
\hline $1^{\prime} \alpha$ & 89.94 & $\mathrm{~S}$ & - & 0 & & & $1^{\prime} \beta, 1^{\prime} \gamma_{\mathrm{d}}, 1^{\prime} \gamma_{\mathrm{u}}, \mathrm{CONH}$ \\
\hline $1^{\prime} \beta$ & 34.18 & $\mathrm{D}$ & 2.080 & 1 & qq & $6.9,6.8$ & $1^{\prime} \gamma_{\mathrm{d}}, 1^{\prime} \gamma_{\mathrm{u}}, \mathrm{CONH}$ \\
\hline $1^{\prime} \gamma_{\mathrm{d}}$ & 15.53 & $\mathrm{Q}$ & 1.147 & 3 & d & 6.9 & $1^{\prime} \beta, 1^{\prime} \gamma_{\mathrm{u}}$ \\
\hline $1^{\prime} \gamma_{\mathrm{u}}$ & 17.00 & $\mathrm{Q}$ & 0.920 & 3 & $\mathrm{~d}$ & 6.8 & $1^{\prime} \beta, 1^{\prime} \gamma_{\mathrm{d}}$ \\
\hline $2^{\prime}$ & 165.86 & $\mathrm{~S}$ & - & 0 & & & $2^{\prime} \alpha$ \\
\hline $2^{\prime} \alpha$ & 55.13 & $\mathrm{D}$ & 4.380 & 1 & dd & $7.0,5.8$ & $2^{\prime} \beta_{\mathrm{d}}, 2^{\prime} \beta_{\mathrm{u}}, 2^{\prime} \gamma_{\mathrm{u}}$ \\
\hline \multirow[t]{2}{*}{$2^{\prime} \beta$} & 33.38 & $\mathrm{~T}$ & 2.139 & 1 & $\mathrm{~m}$ & & $2^{\prime} \alpha, 2^{\prime} \gamma_{\mathrm{d}}, 2^{\prime} \gamma_{\mathrm{u}}, 2^{\prime} \delta$ \\
\hline & & & 1.950 & 1 & $\mathrm{~m}$ & & \\
\hline \multirow[t]{2}{*}{$2^{\prime} \gamma$} & 28.66 & $\mathrm{~T}$ & 1.576 & 1 & $\mathrm{~m}$ & & $2^{\prime} \alpha, 2^{\prime} \beta_{\mathrm{d}}, 2^{\prime} \beta_{\mathrm{u}}, 2^{\prime} \delta, 2^{\prime} \varepsilon$ \\
\hline & & & 1.489 & 1 & $\mathrm{~m}$ & & \\
\hline $2^{\prime} \delta$ & 22.50 & $\mathrm{~T}$ & 1.349 & 2 & $\mathrm{~m}$ & & $2^{\prime} \beta_{\mathrm{d}}, 2^{\prime} \beta_{\mathrm{u}}, 2^{\prime} \gamma_{\mathrm{d}}, 2^{\prime} \gamma_{\mathrm{u}}, 2^{\prime} \varepsilon$ \\
\hline $2^{\prime} \varepsilon$ & 13.95 & Q & 0.880 & 3 & $\mathrm{t}$ & 7.3 & $2^{\prime} \delta$ \\
\hline $3^{\prime}$ & 103.48 & $\mathrm{~S}$ & - & 0 & & & $2^{\prime} \alpha, 3^{\prime} \alpha, 3^{\prime}-\mathrm{OH}$ \\
\hline $3^{\prime} \alpha$ & 64.35 & $\mathrm{D}$ & 3.654 & 1 & ddd & $10.0,6.2,1.8$ & $3^{\prime} \beta_{\mathrm{d}}, 3^{\prime} \beta_{\mathrm{u}}, 3^{\prime}-\mathrm{OH}$ \\
\hline \multirow[t]{2}{*}{$3^{\prime} \beta$} & 26.47 & $\mathrm{~T}$ & 2.191 & 1 & $\mathrm{~m}$ & & $3^{\prime} \alpha, 3^{\prime} \gamma_{\mathrm{d}}, 3^{\prime} \gamma_{\mathrm{u}}, 3^{\prime} \delta_{\mathrm{u}}$ \\
\hline & & & 2.166 & 1 & $\mathrm{~m}$ & & \\
\hline \multirow[t]{2}{*}{$3^{\prime} \gamma$} & 22.18 & $\mathrm{~T}$ & 2.053 & 1 & $\mathrm{~m}$ & & $3^{\prime} \beta_{\mathrm{d}}, 3^{\prime} \beta_{\mathrm{u}}, 3^{\prime} \delta_{\mathrm{d}}, 3^{\prime} \delta_{\mathrm{u}}$ \\
\hline & & & 1.797 & 1 & $\mathrm{~m}$ & & \\
\hline \multirow[t]{2}{*}{$3^{\prime} \delta$} & 45.95 & $\mathrm{~T}$ & 3.618 & 1 & $\mathrm{~m}$ & & $3^{\prime} \beta_{\mathrm{d}}, 3^{\prime} \beta_{\mathrm{u}}$ \\
\hline & & & 3.540 & 1 & $\mathrm{~m}$ & & \\
\hline $3^{\prime}-\mathrm{OH}$ & - & - & 7.329 & 1 & $\mathrm{~d}$ & 1.8 & \\
\hline
\end{tabular}

$a$ axial; $e$ equatorial; $d$ downfield; $u$ upfield 
Czech Republic, isocratic elution with the dichloromethane/methanol 99:1 v/v mixture, flow $7 \mathrm{ml} / \mathrm{min}$, detector set at $345 \mathrm{~nm}$ ). Fractions were pooled according the analytical results of individual fractions (Column Separon SGX NH2, $250 \times 4 \mathrm{~mm}$, I.D., $5 \mu \mathrm{m}$, from Tessek, Czech Republic, isocratic elution with the dichloromethane/methanol 99:1 v/v mixture, flow $2.5 \mathrm{ml} / \mathrm{min}$, detector set at $310 \mathrm{~nm}$, relative retention time of $\gamma$-ergokryptinine was 1.22 with respect to $\alpha$-ergokryptinine). Finally, about $100 \mathrm{mg}$ of $\gamma$ ergokryptinine of purity $>99 \%$ was isolated. Single crystals were prepared by dissolution of $\gamma$-ergokryptinine $(23 \mathrm{mg})$ in methanol $(3.5 \mathrm{ml})$ at $64^{\circ} \mathrm{C}$, subsequent addition of water $(100 \mu \mathrm{l})$, and standing overnight. Mp. $238.8-239.6^{\circ} \mathrm{C}$ (microscope, between cover plates). IR ( $\mathrm{KBr}$ pellet): $\mathrm{O}-\mathrm{H}$ stretching $3309 \mathrm{~m}, \mathrm{C}=\mathrm{O}$ stretching $1665 \mathrm{~s}, 1645 \mathrm{~s}$, and $1729 \mathrm{~s}, \mathrm{C}=\mathrm{C}$ stretching $1564 \mathrm{w}, 1604 \mathrm{w}\left[\mathrm{cm}^{-1}\right]$. UV (acetonitrile): $311 \mathrm{~nm}\left(\varepsilon_{\mathrm{M}}=6.3\right.$. $\left.10^{3} \mathrm{dm}^{3} \mathrm{~mol}^{-1} \mathrm{~cm}^{-1}\right), 241 \mathrm{~nm}\left(\varepsilon_{\mathrm{M}}=1.6 \cdot 10^{4} \mathrm{dm}^{3} \mathrm{~mol}^{-1} \mathrm{~cm}^{-1}\right)$.

\subsection{Crystallographic study}

$\gamma$-Ergokryptinine $\mathrm{C}_{32} \mathrm{H}_{41} \mathrm{~N}_{5} \mathrm{O}_{5}, \quad M_{r}=575.71$, orthorhombic, space group $P 22_{1} 2_{1} 2_{1}, a=6.5600(1), b=17.8830(3), c=25.4550(4) \AA, \quad V=$ 2986.19(8) $\AA^{3}, Z=4, D_{c}=1.280 \mathrm{~g} \mathrm{~cm}^{-3}$, Nonius Kappa CCD area-detector diffractometer, $\varphi$ and $\omega$ scans technique, $\operatorname{Mo} K_{\alpha}$ radiation, $\lambda=0.71073 \AA$, $\mathrm{T}=150(2) \mathrm{K}$. A total of 51419 reflections were measured $(h-8 \rightarrow 8$, $\left.k-23 \rightarrow 23, l-32 \rightarrow 33, \theta_{\max }=27.48^{\circ}\right)$. Merging equivalents gave 5401 unique reflections $\left(\mathrm{R}_{\mathrm{int}}=0.07\right)$, of which 3034 were unique and observed (I $>1.96 \sigma(\mathrm{I}))$ and used for the refinement. The structure was solved by direct methods and anisotropically refined. The $\mathrm{H}$-atoms were placed in their calculated positions and allowed to ride on their attached $\mathrm{C}$-atoms in distances of $1.0 \AA$. The atoms H511, H531 and H551 were located in difference Fourier maps and refined fixed. The minimized function was $\Sigma w\left(F_{o}-F_{c}\right)^{2}$, where $w=[$ weight $]\left[1-(\delta F / 6 \sigma F)^{2}\right]^{2}$, (Prince, 1982; Watkin, 1994), $(\Delta / \delta)_{\max }=0.0003, R=0.042, S=1.075$ with the largest residual peaks of -0.23 and $0.19 \mathrm{e} \cdot \AA^{-3}$. Data collection: COLLECT (Nonius, 1997); cell refinement: DENZO/SCALEPACK (Otwinowski and Minor, 1997); data reduction: DENZO/SCALEPACK; program used to solve structure: SHELXS86 (Sheldrick, 1986); program used to refine structure: CRYSTALS (Watkin et al., 2001); molecular graphics: ORTEP-3 (Farrugia, 1997).

Important backbone conformation angles $\left[{ }^{\circ}\right]$ : Val: $\varphi_{2}=-63.6(3)$, $\psi_{2}=112.1(2), \omega_{2}=-178.3(2), \chi_{2}{ }^{1,1}=176.2(2), \chi_{2}{ }^{1,2}=-59.5(3)$; Nle: $\varphi_{3}=-147.3(2), \quad \psi_{3}=2.6(3), \quad \omega_{3}=-5.1(4), \quad \chi_{3}{ }^{1}=-49.4(3), \quad \chi_{3}{ }^{2}=$ $-171.3(2), \chi_{3}^{3}=-58.6(3)$; Pro: $\varphi_{4}=-22.6(3), \psi_{4}=49.5(2)$. Full data are deposited with the Cambridge Crystallographic Data Centre.

$\alpha$-Ergokryptinine (IVAX Pharmaceuticals, crystallised from methanol/ water) $\mathrm{C}_{32} \mathrm{H}_{41} \mathrm{~N}_{5} \mathrm{O}_{5}, M_{r}=575.71$, orthorhombic, space group $P 2_{1} 2_{1} 2_{1}$, $a=6.571(1), \quad b=18.337(4), \quad c=26.234(5) \AA, \quad V=3161(1) \AA^{3}, \quad Z=4$, $\mathrm{D}_{\mathrm{c}}=1.210 \mathrm{~g} \mathrm{~cm}^{-3}$, Nonius CAD4 diffractometer, $2 \theta / \omega$ scans technique, $\mathrm{Cu} K_{\alpha}$ radiation, $\lambda=1.54184 \AA$, $\mathrm{T}=293 \mathrm{~K}$. A total of 6283 reflections were measured $\left(h 0 \rightarrow 8, k 0 \rightarrow 22, l-31 \rightarrow 31, \theta_{\max }=69.93^{\circ}\right), 5130$ of them were unique and observed $(\mathrm{I}>2 \sigma(\mathrm{I}))$ and included in the structure analysis. The structure was solved by direct methods and anisotropically refined. C28 in the valine residue is disordered in two positions labelled as C28 of occupancy 0.68(1) - conformation denoted as A, and C28', occupancy 0.32(1) - B. The most of the leucine residue is disordered in two branches - C30, C31 and C32 of occupancy 0.29(2) - A, and C30', C 31' and $\mathrm{C} 32^{\prime}$ of occupancy 0.71(2) - B. The H-atoms were located in difference Fourier maps and isotropicaly refined, except of H1, H4, H52, H232, which were refined riding in distance of $0.95(1) \AA$ and those H-atoms in disordered residues, that were refined riding in their calculated positions with their respective occupancy values. The minimized function was $\Sigma w\left(F o^{2}-F c^{2}\right)^{2}$, where $w=1 /\left[\sigma^{2}\left(F o^{2}\right)+(0.1236 P)^{2}+1.0004 P\right]$ and $P=\left(F o^{2}+2 F c^{2}\right) / 3,(\Delta / \delta)_{\max }=-0.005, R=0.0670, S=1.028$ with the largest residual peaks of -0.18 and $0.74 \mathrm{e} \cdot \AA^{-3}$. Data collection, cell refinement and data reduction: SDP (Frenz, 1985); program used to solve structure: SHELXS86 (Sheldrick, 1986); program used to refine structure: SHELXL (Sheldrick, 1993).
Important backbone conformation angles $\left[{ }^{\circ}\right]$ : conformation of Val: $\varphi_{2}=-47.2(5), \psi_{2}=112.1(2), \omega_{2}=-177.8(3), \chi_{2}{ }^{1,2}=-63.0(5)$, conformation of Val A: $\chi_{2}{ }^{1,1}=166.6(5)$, conformation of Val $\mathbf{B}: \chi_{2}^{1,1}=65(1)$; Leu: $\varphi_{3}=-149.5(3), \psi_{3}=-7.9(5), \omega_{3}=0.9(6)$, conformation of Leu $\mathbf{A}$ : $\chi_{3}{ }^{1}=-63(1), \chi_{3}{ }^{2,1}=-58(2), \chi_{3}{ }^{2,2}=179(2)$; conformation of Leu $\mathbf{B}$ : $\chi_{3}{ }^{1}=157(1), \chi_{3}^{2,1}=-87(1), \chi_{3}^{2,2}=179(2)$; Pro: $\varphi_{4}=-19.8(5), \psi_{4}=$ 44.5(4). Full data are deposited with the Cambridge Crystallographic Data Centre.

CCDC contains the supplementary crystallographic data for this paper: $\gamma$-ergokryptinine CCDC 227875 and $\alpha$-ergokryptinine CCDC 227876. These data can be obtained free of charge via www.ccdc.cam.ac.uk/ conts/retrieving.html (or from the CCDC, 12 Union Road, Cambridge CB2 1EZ, UK; fax: +44 1223 336033; e-mail: deposit@ccdc.cam.ac.uk)

\section{Results and discussion}

In our program of searching for potential impurities of ergotoxine, we identified an unusual ergopeptine containing norleucine. A crude alkaloid concentrate was obtained by the extraction of an ergot strain producing $\alpha$-ergokryptine (Claviceps purpurea CCM 8059), but was also found in other ergot strains producing ergotoxine. The concentrate of $\alpha$-ergokryptine was crystallised from toluene and the mother liquors were concentrated and converted to a mixture of ergopeptinines by crystallisation from methanol. The mixture of ergopeptinines was then separated by chromatography on a silica gel. Finally, $\gamma$-ergokryptinine fraction was purified by preparative HPLC and crystallised from methanol/water.

Mass spectrometry revealed that the compound is isobaric with $\alpha$ - or $\beta$-ergokryptines $\left(\mathrm{C}_{32} \mathrm{H}_{41} \mathrm{~N}_{5} \mathrm{O}_{5}\right)$. Also the $\mathrm{ms}^{2}$ of the $[\mathrm{M}+\mathrm{H}]^{+}$ion $\mathrm{m} / \mathrm{z} 576$ provided identical fragment ion $\left[\mathrm{M}+\mathrm{H}-\mathrm{H}_{2} \mathrm{O}\right]^{+} \mathrm{m} / \mathrm{z} 558$ and ion $\mathrm{m} / \mathrm{z} 348$, representing the splitting of the diketopiperazine moiety. The later ion, analogous to the fragmentation observed under EI conditions (Crespi-Perellino et al., 1987), makes it possible to calculate the summary composition of the side chains of the first and second amino acid of the tripeptide moiety as $\mathrm{C}_{3} \mathrm{H}_{7}$ and $\mathrm{C}_{4} \mathrm{H}_{9}$, respectively, but lacks the information about the structure and chirality of these side chains.

The observation of three carbonyls and two $s p^{3}$-hybridized carbons attached to two heteroatoms each shows that the investigated compound belongs to ergot peptide alkaloids. There are thirty-two signals in the ${ }^{13} \mathrm{C}$ NMR spectrum: four methyls, eight methylenes, ten methines (four $=\mathrm{CH}$ among them), and ten quaternary carbons. Thirty-eight hydrogens are bonded to carbons; three to heteroatoms (two $\mathrm{N}-\mathrm{H}$ 's and one $\mathrm{OH}$, see below). These facts verify the summary formula $\mathrm{C}_{32} \mathrm{H}_{41} \mathrm{~N}_{5} \mathrm{O}_{5} .{ }^{1} \mathrm{H}$ NMR spectrum contains, besides the singlets of $\mathrm{N}$-methyl and $\mathrm{CONH}$, a three-spin system made of vicinal aromatic protons, and partial structures $\left(\mathrm{CH}_{3}\right)_{2} \mathrm{CH}-, \mathrm{NCH}\left(\mathrm{CH}_{2}\right)_{3} \mathrm{CH}_{3},-\mathrm{NHCH}=$ $\mathrm{CCH}_{2} \mathrm{CHC}=\mathrm{CHCH}(\mathrm{X}-) \mathrm{CH}_{2}-, \mathrm{C}(\mathrm{OH}) \mathrm{CHN}\left(\mathrm{CH}_{2}\right)_{3}$. Indole 
$\mathrm{NH}, \mathrm{CONH}$ and $3^{\prime}-\mathrm{OH}$ were easily differentiated according to their coupling pattern in HMBC (Fig. 2). This experiment also determines the attachment of $\mathrm{CONH}$ to C-8 (X above) and the location of N-methyl between C5 and C7. Therefore, the molecule contains a 9-ergolene moiety. To determine the configuration at $\mathrm{C} 8$, the conformation of the ring D has to be solved first (Pierri et al., 1982; Cvak et al., 1994a). Coupling $\mathrm{J}_{8,9}=6.4 \mathrm{~Hz}$ means a pseudoequatorial $\mathrm{H} 8$. Chemical shift of $\mathrm{CONH}$ proton corresponds to its participation in hydrogen bonding; that of H5 (3.239 ppm) is diagnostic for a trans arrangement of $\mathrm{H} 5$ and the nitrogen lone electron pair (Bailey and Grey, 1972). Therefore, the D-ring exists in so-called flap-up conformation and the cyclol is $8 \alpha$ - attached (i.e., indeed an "-inine"). Isolated isopropyl group is attached to $\mathrm{C}^{\prime} \alpha$. The $n$-butyl side chain is attached to $\mathrm{C}^{\prime} \alpha$ and the proline is located in its usual position. Long-range coupling between $\mathrm{H} 2^{\prime} \alpha$ and $\mathrm{H}^{\prime} \alpha$ suggest that both these atoms are located on the same side of the (modified) diketopiperazine ring.

The final structural proof was provided by the crystal structure determination, Fig. 3. The X-ray study has confirmed the elemental composition, presence of norleucine in $\gamma$-ergokryptinine and provided relative configuration of all its chiral centres. Up to now, only few X-ray structures of norleucine (Harding et al., 1995) or its synthetic derivatives (Nigovic et al., 1992; Fenude and Casalone, 1996) have been reported. Structure of $\gamma$ ergokryptinine is apparently the first X-ray structure of natural norleucine-containing secondary metabolite. The conformation of $\gamma$-ergokryptinine is very close to

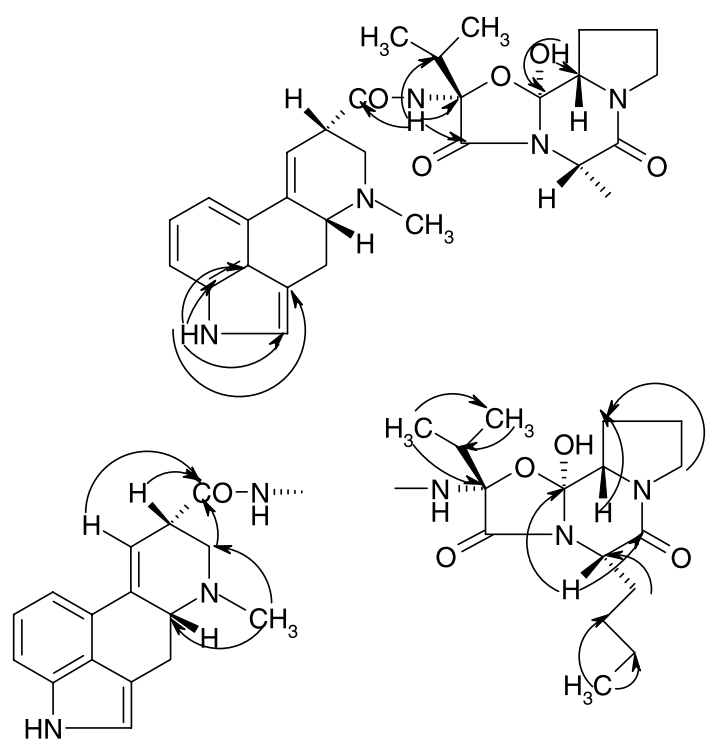

Fig. 2. Long range couplings in NMR spectrum of $\gamma$-ergokryptinine

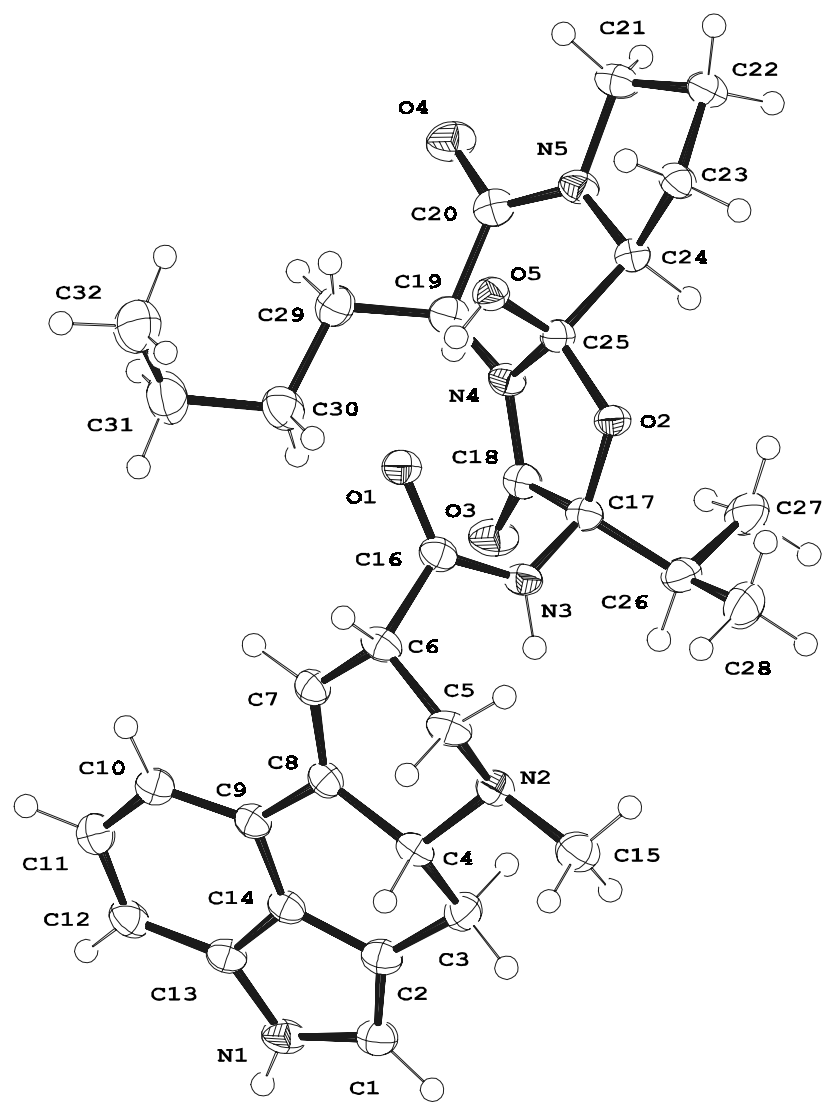

Fig. 3. ORTEP drawing of $\gamma$-ergokryptinine, thermal elipsoids are drawn at $50 \%$ probability

that found in ergoladinine structure (Cvak et al., 1996). The almost isostructural molecular packing explains this surprisingly high similarity. The analogous force fields of the neighbours allow molecules to settle in similar conformations and vice versa the chemical and sterical demands of the molecules make the compounds crystallise in the same structural type. For comparison, the crystal structure of $\alpha$-ergokryptinine was also determined. Despite some obvious differences in the conformation of the side chain of leucine (see Experimental), this third structure of ergopeptinines determined so far indicates that these compounds tend to prefer the same structural arrangement.

There are two intramolecular hydrogen bonds in the structure of $\gamma$-ergokryptinine: the obligatory O5-H551 .. O1 typical for ergopeptine alkaloids and N3-H531 ... N2, which stabilises the 'flap-up' conformation present in bases only. The only intermolecular bond is provided by N1H511 ... 4 4 $(-\mathrm{x}+1 / 2,-\mathrm{y},+\mathrm{z}-1 / 2)$, which forms infinite chains along the $2_{1}$ screw axis in $\mathrm{Z}$ direction. This interaction appears to be responsible for the needle-like shape of the crystals. 
$\gamma$-Ergokryptinine belongs to the iso-lysergic acid series (-inines) with the $8 \alpha$ configuration at the $\mathrm{C}-8$ atom. Similarly as with other series of secondary metabolites synthesised extraribosomally by multienzyme system (Keller, 1999), the possibility that norleucine can be incorporated instead of aliphatic amino acids is not unexpected and has already been detected by in vitro experiments (Beacco et al., 1978). Moreover, also the misincorporation of norleucine (amino acid side chain $-\left(\mathrm{CH}_{2}\right)_{3}-\mathrm{CH}_{3}$ ) instead of methionine $\left(-\left(\mathrm{CH}_{2}\right)_{2}-\mathrm{S}-\mathrm{CH}_{3}\right)$ is well known even with ordinary protein synthesis (Jakubowski and Goldman, 1992). It is worth mentioning that just methionine containing ergot alkaloid was described recently (Cvak et al., 1996). Thus, $\gamma$-ergokryptinine is the $8^{\text {th }}$ member of ergotoxine (-inine) series (Bianchi et al., 1982; Cvak et al., 1994b, 1996).

\section{Acknowledgements}

This work was supported by the Ministry of Education, Youth and Sports of the Czech Republic (research project No. CEZ: MSM 6046137302) and by the Grant Agency of the Czech Republic (GACR 203/99/M037).

\section{References}

Abe M, Fukuhara T, Ohmono S, Hori M, Tabuchi T (1976) Production of alkaloids and related substances by fungi. Part VII. Isolation of prolyldiketopiperazines corresponding to peptide portions of peptidetype alkaloids from sclerotia and saprophytic cultures of Ergot fungi. J Agr Chem Soc Japan 50: 543-579

Atwell SM, Mantle PG (1981) Hydroxydihydroergosine, a new ergot alkaloid analogue from directed biosynthesis by Sphacelia sorghi. Experientia 37: 1257-1258

Bailey K, Grey AA (1972) Conformational study of lysergic acid and isolysergic acid dialkylamides by proton magnetic resonance spectroscopy. Can J Chem 50: 3876-3885

Baumert A, Erge D, Gröger D (1982) Incorporation of thiazolidine-4carboxylic acid into ergosine by Claviceps purpurea. Planta Med 44: $122-123$

Beacco E, Bianchi ML, Minghetti A, Spalla C (1978) Directed biosynthesis of analogues of ergot peptide alkaloids with Claviceps purpurea. Experientia 34: 1291-1293

Bianchi ML, Crespi Perellino N, Gioia B, Minghetti A (1982) Production by Claviceps purpurea of two new peptide ergot alkaloids belonging to a new series containing $\alpha$-aminobutyric acid. J Nat Prod 45: 191-196

Buchta M, Cvak L (1999) Ergot alkaloids and other metabolites of the genus Claviceps. In: Křen V, Cvak L (eds) Ergot. The genus Claviceps. and aromatic plants - Industrial profiles, vol. 6. Harwood Academic Publishers, Amsterdam, pp 173-200

Crespi-Perellino N, Ballabio M, Gioia B, Minghetti A (1987) Two unusual ergopeptines produced by a saprophytic culture of Claviceps purpurea. J Nat Prod 50: 1065-1074

Crespi-Perellino N, Malyszko J, Ballabio M, Gioia B, Minghetti A (1992) Directed biosynthesis of unnatural ergot peptide alkaloids. J Nat Prod 55: 424-427

Crespi-Perellino N, Malyszko J, Ballabio M, Gioia B, Minghetti A (1993) Identification of ergobine, a new natural peptide ergot alkaloid. J Nat Prod 56: 489-493
Cvak L, Stuchlík J, Schreiberová M, Sedmera P, Havlíček V, Flieger M (1994a) 2,3-Dihydro-2-oxoergolene derivatives, Collect. Czech Chem Commun 59: 929-942

Cvak L, Jegorov A, Sedmera P, Havlíček V, Ondráček J, Hušák M, Pakhomova S, Kratochvíl B, Granzin J (1994b) Ergogaline, a new ergot alkaloid, produced by Claviceps purpurea: Isolation, identification, crystal structure and molecular conformation. J Chem Soc, Perkin Trans 2: 1861-1865

Cvak L, Minář J, Pakhomova S, Ondráček J, Kratochvíl B, Sedmera P, Havlíček V, Jegorov A (1996) Ergoladinine, an ergot alkaloid. Phytochemistry 42: 231-233

Farrugia LJ (1997) ORTEP-3 for Windows - a version of ORTEP-III with a Graphical User Interface (GUI) by J. Farrugia. J Appl Cryst 30: 565-565

Fenude E, Casalone G (1996) Three protected tetrapeptides. Acta Crystallographica C52: 973-978

Flieger M, Sedmera P, Vokoun J, Řeháček Z, Stuchlík J, Malinka Z, Cvak L, Harazim P (1984) New alkaloids from a saprophytic culture of Claviceps purpurea. J Nat Prod 47: 970-976

Frenz BA, Associates Inc. (1985) SDP. Structure determination package. Enraf-Nonius, Delft, The Netherlands

Halada P, Sedmera P, Havlíček V, Jegorov A, Cvak L, Ryska M (1998) Mass spectrometric amino acid structure determination in ergopeptines. Eur. Mass Spectrom 4: 385-392

Harding MM, Kariuki BM, Williams L, Anwar J (1995) DL-Norleucine: redetermination of structure and observations with synchrotron radiation Laue diffraction on heating towards transformation. Acta Cryst B51: 1059-1062

Jakubowski H, Goldman E (1992) Editing of errors in amino acids selection for protein synthesis. Microbiol Rev 56: 412-429

Jegorov A, Šimek P, Heydová A, Cvak L, Minár J (1997) Free and bonded homoisoleucine in sclerotia of the parasitic fungus Claviceps purpurea. Amino Acids 12: 9-19

Jenett-Siems K, Kaloga M, Eich E (1994) Ergobalansine/ ergobalansinine, a proline-free peptide-type alkaloid of the fungal genus Balansia, is a constituent of Ipomea piurensis. J Nat Prod 57: 1304-1306

Keller U (1999) Biosynthesis of ergot alkaloids. In: Křen V, Cvak L (eds) Ergot. The genus Claviceps. and aromatic plants - Industrial profiles, vol. 6. Harwood Academic Publishers, Amsterdam, pp 95-163

Nigovic B, Kojic-Prodic B, Puntarec V (1992) Structure of a biologically active conjugate of auxin: $N$-indol-3-ylacetyl-L-norleucine at 297 and 133 K. Acta Cryst C48: 1079-1082

Nonius (1997) COLLECT. Nonius BV Delft, The Netherlands

Otwinowski Z, Minor W (1997) Processing of X-Ray diffraction data collected in oscillation mode. In: Methods in enzymology, vol. 276. Macromolecular crystallography, Part A. In: Carter CW Jr, Sweet RM (eds) Academic Press, New York, pp 307-326

Pierri L, Pitman IH, Rae ID, Winkler DA, Andrews PR (1982) Conformational analysis of the ergot alkaloids ergotamine and ergotaminine. J Med Chem 25: 937-942

Pöhm M (1954) Über zwei neue Peptid-Alkaloide aus Mutterkorn. Monatsh 85: 1010-1012

Powell RG, Plattner RD, Yates SG, Clay K, Leuchtmann J (1990) Ergobalansin, a new ergot-type peptide alkaloid isolated from Cenchrus echinatus (Sandbur grass) infected with Balansia obtecta and produced in liquid culture of B. obtecta and Balansia cyperi. J Nat Prod 53: 1272-1279

Prince E (1982) Mathematical techniques in crystallography and materials science. Springer, New York

Sheldrick GM (1986) SHELXS86. Program for crystal structure solution. University of Göttingen, Germany

Sheldrick GM (1993) SHELXL93. Program for the refinement of crystal structures. University of Göttingen, Germany 
Schlientz W, Brunner R, Rüegger A, Berde B, Stürmer E, Hofmann A (1967) $\beta$-Ergokryptine, a new alkaloid of the ergotoxine group. Experientia 23: 991-992

Stadler PA (1982) Neuere Ergebnisse der MutterkornalkalkoidForschung. Planta Med 46: 131-144

Szántay C Jr, Bihari M, Brlik J, Csehi A, Kassai A, Aranyi A (1994) Structural elucidation of two novel ergot alkaloid impurities in $\alpha$-ergokryptine and bromokryptine. Acta Pharm Hung 64: $105-108$

Vázquez MJ, Roa AM, Reyes F, Vega A, Rivera-Sagredo A, Thomas DR, Díez E, Hueso-Rodríguez JA (2003) A novel ergot alkaloid as a $5-\mathrm{HT}_{1 \mathrm{~A}}$ inhibitor by Dicyma sp. J Med Chem 46: $5117-5120$
Watkin DJ (1994) The control of difficult refinements. Acta Cryst A50: 411-437

Watkin DJ, Prout CK, Carruthers JR, Betteridge PW, Cooper RI (2001) CRYSTALS. Issue 11. Chemical Crystallography Laboratory, Oxford, England

Yates SG, Plattner RD, Garner GB (1985) Detection of ergopeptine alkaloids in endophyte infected, toxic Ky-31 tall fescue by mass spectrometry/mass spectrometry. J Agric Food Chem 33: 719-722

Authors' address: Alexandr Jegorov, IVAX Pharmaceuticals, R\&D, Branišovská 31, 37005 České Budějovice, Czech Republic,

Fax: 420-38-5310397, E-mail: alexandr_jegorov@ivax-cz.com 